\title{
Issues Concerning the Relationship between Accounting and Taxation in Determining Financial Result
}

\author{
Florentina Moisescu ${ }^{1}$
}

\begin{abstract}
The tax result does not reflect the real financial performance of a company but rather shows a result of taxation which is to determine the size of tax for a company. Therefore, in Romanian accounting there are a lot of different ways which are used to obtain an 'embellished accounting result due to a large variety of accounting policies and methods which allows the company to choose the desired outcome. In our county, the main goal of an enterprise seems to be either the decrease of the financial result in order to avoid payment of a bigger tax to the state tax authority or the postponement of it, while companies from other countries want a financial result as big as possible so that they can attract investors.
\end{abstract}

Keywords: financial outcome, accounting, fiscality, accountig policy, revenue, cost, tax

\section{Introduction}

The issue of company earnings is the main consequence of the disconnection between accounting and taxation. Any organization must provide accounting information characterized by fairness, truth, clarity and precision so that all its users are able to make the right decision regarding the respective company.

Companies are often accused of bias in setting the accounting result, its value being determined by the different objectives of the enterprise. Administrators of economic entities should determine the outcome of the company in such away that they don t have fiscal obligations that are too high, nor do they get into conflict with their employees, suppliers or customers. ${ }^{[1]}$

This topic has been discussed by several authors. In his book "Liberty and conformation according to accounting standards and regulations" professor Mihai Ristea ventured, says that over time the conflict between taxation and accounting is the one which made more ink to flow. ${ }^{[2]}$ Mediating this conflict concerns the discovery to what extent the two depend on each other and of the differences between accounting and tax rules.

In his book "Taxation and Accounting in the company", the author Costel Istrate says that the difference between tax and accounting becomes apparent from the purpose of the two: establishing bases for tax is the accounting`s objective, while the burden of taxation is to define rules to better adapt accounting functions. [3]

The cause of this conflict is the existence of differences between the two in terms of economic calculation and evaluation, as tax rules do not seek to obtain a true and fair 
view of the economic entity, but the stimulation or inhibition of activity. The author, Adriana Popa Florentina, believes that "while accounting profit reflects the application of accounting principles for measuring fair activity, fiscal profits are relevant the tax authority". [1]

We must, however, be aware that as part of the management of business taxation, accounting has a very important role in the efficient operation of taxation because the provided accounting data generates the various tax liabilities of the economic entity.

The financial result is a miniature view of the economic activity of a company. It presents a statement of revenue and expenditure of a company in a financial year and it is an important indicator of its financial health.

The financial result of a company is determined first as accounting result and then as a financial result. Both can be classified as either profits or losses.

The accounting result is the difference between income and expenses specific to a financial year before tax. On the other hand, setting the financial results is a more difficult work and requires compliance with the legal provisions of the Tax Code, which includes the method of calculating income tax.

The political power has an important role in the accounting-taxation relationship through the degree of state involvement in the economy and economic policy promoted. Also, different values of corporate tax rates internationally are tackled in this paper. Each state sets its corporate tax level depending on their objectives, but also economic and social development at its disposal.

\section{Determining the Accounting Result}

European countries have different visions of calculating the company`s result according to the relationship between accounting and taxation, thus: the continental and Anglo-Saxon model.

The continental model, specifical to Germany, France, Italy and Romania, is characterized by the predominance of state intervention and the dependence of taxation on accounting. In the countries that apply this model, reliable accounting information is provided by the principles of accounting, reliability being a more a legal concept.

The Anglo-Saxon model involves determination of the result without considering national fiscal rules. Since the main goal is to present a true and fair view of the company and the economic reality it is ensured "a greater degree of objectivity in presenting the situation of the enterprise "[1] and the target users in this case are represented by investors. This model is put in practice in the UK, Ireland, the Netherlands, but also in countries outside Europe more specifically the United States, Canada and Australia.

Each of these schemes has advantages and disadvantages. If separate tax rules, two sets of rules must be applied, which may increase the bureaucratic burden on businesses. It may also be easier to deviate for tax purposes of certain principles of commercial accounting. But even when taxation is based on the commercial accounts, certain tax adjustments are unavoidable.

It is unrealistic to expect a complete harmonization between the two areas. Each state has the right to choose one of two modes for setting the financial result.

The convergence of the two areas is difficult, because each targeting different purposes. 
Accounting rules are considering the determination of profit or loss at the end of the financial year. Accounting rules aim at respecting the rights of shareholders and provide a more accurate image of investors on the financial performance of the company.

On the other hand, fiscal rules aim at determining the tax liability of a company in a given period. These tax rules are designed such as to ensure economic neutrality, each company obeying the same set of fiscal rules.

The accounting result or gross result is determined by the matching principle and accrual. Internationally and in our country, creative accounting practices are often used to achieve a satisfactory result for the company. In obtaining this result an important role have the choice and application of accounting policies, which requires a flexible process based on professional judgment of accounting. ${ }^{[4]}$

Using this practice is possible due to economic and financial transactions carried out by vastly different enterprises, which makes uniform reporting process is not easy to achieve. [4]

The most commonly used accounting policy for arranging financial results are:

- the policy of common recognition of revenue and expenditure;

- the policy on depreciation of property, plant and equipment;

- the policy on the cost of borrowing;

- the policy on stock assessment output.

- The policy regarding the recognition of revenue and expenses expresses directly its influence on the outcome of the economic unit which is represented by the elements composing it. Therefore, in order for the accountants to change the outcome, they must recognize some uncertain income to be likely the result of current activity, some income earned by imprudent conduct transactions involving a rather high risk or some income from overpricing progress and ongoing provision.

Regarding expenses, they are used as instruments of financial performance by not recognizing expenses with some degree of uncertainty, and using inappropriate methods of evaluating economic reality, reducing all costs for work in progress or nonregistration adjustments impairments that are necessary to decrease the stocks.

- Depreciation policy influences tangible result of the company through annual depreciation recognized as an expense in the period. National legislation provides three methods of depreciation of property: linear depreciation, amortization and accelerated depreciation diminishing. However, in the Tax Code there are two more methods mentioned, one for depreciation per unit product: "depreciation of buildings and construction of mines, mines with extraction solution by wells, quarries, mining for the day, and the solid minerals oil extraction, whose duration of use is limited to the duration of reserves and cannot receive other uses after depletion and investment for overburden is calculated per unit of product, depending on the useful exploitable mineral substance" and a method based on the number of kilometers or the number of operating hours: "means of transportation can be written through the number of miles or the hours of operation written in the manuals for those purchased after January 1, 2004".

On the other hand, the International Financial Reporting Standards, namely IAS 16 "Intangible assets" recognizes only three methods of depreciation: the linear depreciation method, the diminishing balance method and the units of production. When using linear depreciation, there is a uniformity of expenses over time. This method is often used and 
it is fairly straightforward, but does not account for the decrease in production capacity or the increase of maintenance costs due to wear.

However, it reduces the tendency of traders to ignore the tax rules. Degressive depreciation, as well as the accelerated involves reducing earnings in the first year by recording higher depreciation expenses and increasingly smaller in the coming years, giving investors the impression that the company benefits from an increase in financial performance from year to year. Thus, we can say that by using these two methods it allows economic unit to receive an economic advantage.

- The policy on the cost of borrowing is treated in International Financial Reporting Standard IAS 23 and refers to the interest and other costs that an entity incurs as a result of contracting loans. This policy comes on the value of the result in increase or decrease, depending on whether that entity chooses the capitalization of the interest or the registration in the Profit and Loss account. If they choose the interest capitalization, the financial result is now higher and interest costs are recognized in the cost of acquisition or production of the asset. If the expense is recognized in the income statement then the result will be lower and hence tax will be lower.

- The policy on stock assessment output

Regarding stock assessment output there is a mismatch between the Romanian and international law, because in IAS 2 "Inventories" are recognized as inventory evaluation methods: the weighted average cost method and the first-in- first out method while the national law recognizes, in addition to the two, and the last in-first out method. Applying the FIFO is done at lower prices and leads to an increase in earnings, while the use of LIFO decreases both the result and the tax and by the FMC method it will get a smaller value of stocks than when using the FIFO method. The first-in-first-out method reveals best actual physical flow statement, while the LIFO method provides a realistic view of costs.

\section{Determining Tax Earnings}

The tax result is calculated in accordance with tax principles, as the difference between revenue and costs incurred to achieve those revenues in a fiscal year, to which non-deductible expenses are added and non-taxable income and tax deductions are substracted, but also the losses for the past years, if any. Computation result is the following:

\section{Result $=$ Result sheet + Tax deductible expenses - Taxable income $/$ Tax deduction.}

In calculating the accounting or tax result are taken into account all income made by a company in a given period and all expenses incurred to obtain these revenues. There are also partially deductible expenses, including:

a) Hospitality in the limit of $2 \%$ of the difference between total revenue and total expenditure. Of the total expenses are eliminated current tax expense and deferred expenses, entertainment expenses and taxable income and there are added VAT expenses collected for the gifts offered by the taxpayer equal to or greater than 100 lei.

b) Social expenditures in the limit of $2 \%$ of the value of the wage bill, this including aid 
for birth, funeral, incurable diseases or prostheses for children in foster care, etc.

c) Expense provisions and reserves are shown in the Tax Code:

- The legal reserve is deductible in the limit of $5 \%$ of accounting profit minus taxable income and added expenses incurred to obtain these revenues until it reaches the fifth subscribed and paid up share capital of the unit. If the reservation is used to cover losses, restoring them is not considered a tax deductible expense.

- Provisions for performance guarantees for customers constitute only quarterly for the goods, the performed work or services rendered in that quarter. These provisions shall be canceled on the basis of income as there are remediation costs made or the expiry of the warranty period specified in the contract.

- Provisions established in the limit of 20\% from 1 January 2004, 25\% from 1 January 2005 and 30\% since January 1, 2006 from the value of claims on customers who meet the following conditions: they are registered after 1 January 2004, they are not received within a period exceeding 270 days from the due date, they are not guaranteed by another person, they are due to a person who is an affiliated person of the economic entity and were included in the taxable income of the company. Provisions are canceled or reduced when charged fully or partially.

The provisions for claims in foreign currencies are deductible by favorable or unfavorable exchange differences that arise when assessing value. Expenses for doubtful debts or losses are deductible on unpaid dispute provision set.

- Provisions set in the limit of $100 \%$ of the debts owed by customers if there are satisfied the following conditions: they are registered after January 1, 2007, the claim belongs to a company which has been declared opened for bankruptcy proceedings based on judgment, they are not guaranteed by another person, they are payable by a person who is not an affiliated person of the economic entity and they were included in the taxable income of the company.

d) Interest expenses and exchange differences are deductible when capital indebtedness is less than or equal to 3, the capital indebtedness being determining as a ratio of borrowed capital repayment longer than one year and equity.

In calculating the tax result, the following income which is not taxable is taken into account:

- Dividends received from a Romanian or foreign legal entity from a third country that pays income tax or a tax like this, in the condition in which Romania has a convention for the avoidance double taxation with the third country, and if the legal person receiving such income has $10 \%$ of the share capital of the company from the third country. After joining the European Union, dividends received from Romanian legal entities, parentcompanies situated in Member States and those received from legal persons of the Member States with permanent establishment in Romania, are considered non-taxable income;

- Income from cancelling expenses which are not considered deductible - in this category are included: tax refunds paid in earlier years and income from cancellation of provisions considered expenses when they were set in;

- Income from transfer or sale of shares held in a Romanian company or a foreign one located in a state with which Romania has concluded a convention for the avoidance of double taxation; 
- Income from liquidation of a Romanian company or a foreign company located in a state with which Romania has concluded a convention for the avoidance of double taxation.

- Revenues from the recorded deferred and determined tax of companies which apply International Financial Reporting Standards.

\section{Tax Payment and Income Tax Declaration}

All tax payers have to pay an amount of $16 \%$ of the income, except for night spots, casinos, night clubs and economic agents that have as activity sport bets, which have to pay the maximum value between $16 \%$ of the taxable profit and $5 \%$ of the incomes obtained during that period.

According to the fiscal code, there is a difference between societies and microenterprises as far as the tax listing is concerned. Microenterprises are those societies which have a turnover smaller than $65,000 €$ and which obtain incomes from consulting activities and management in a percentage smaller or equal to $20 \%$ of the whole amount of incomes and pay a tax of $3 \%$ of the realized incomes.

If the incomes of these societies exceed $65,000 €$ or the incomes from consulting and management get over $20 \%$ of the total incomes, the society will start to pay the tax on profit, beginning with the trimester in which these overflows took place, taking into account all the expenses and incomes from that fiscal year.

Income taxes paid quarterly until the 25th, including the first month following the quarter for which the tax is calculated with the following exceptions:

$>$ The National Bank of Romania, banking companies Romanian legal persons and branches in Romania of banks foreign legal persons pay tax monthly, until the 25th, including, of the month for which the tax is calculated;

$>$ Non-profit organizations pay tax annually until 15 February, inclusive, of the following year for which the tax is calculated;

The companies which derive income mainly from cultivating cereals and technical plants, fruit and viticulture pay tax annually until 15 February, inclusive, of the following year for which the tax is calculated.

The companies which make quarterly payments or pay monthly for the last quarter or December, an amount equal to the tax calculated and revealed to the third quarter of the same fiscal year or an amount equal to tax calculated and revealed to November of that fiscal year. The final payment of income tax for the fiscal year is set as deadline for submission of annual financial statements.

Accordin to Tax Code, more categories of taxpayers are exempt from corporation tax, such as:

- State Treasury

- public institutions

- Romanian legal entities that pay income tax on microenterprises

- Roman foundations established as a result of a legacy

- denominations

- accredited private educational institutions 
- homeowners associations constituted as legal entities and residents' associations recognized as owners associations

- Bank Deposit Guarantee Fund

- Investor Compensation Fund

- National Bank of Romania

- Private Pension System Rights Guarantee Fund

The completion and submission of the statement of commercial companies is to establish tax payable or recoverable, being also the request for payment of the tax.

Income tax declaration is submitted annually to the deadline for submitting financial statements, except for those who make up to February 15, including the following year.

Declaration on the tax-payer is drawn receivable title which finds and specifies the obligation to pay the tax.

\section{Fiscal Implications on Accounting Principles}

In our country, since the state is the primary user of accounting information, businesses tend to diminish the result sheet to shrink their tax burden. They manage this with the accounting principles and policies, thus creating differences between the accounting and the tax results.

Most times, the accounting result provides insight into the company closer to reality than the tax result because when the tax result is established, an accounting loss can be converted into tax profit and taxed. Accounting principles responsible for the emergence of differences between the two types of result are:

1. Accrual

According to this principle, "the expense will be recorded in the accounts when it is liable, not when it is paid and the income when there is a right to receive cash and not when received". [4]

The development of economic transactions respecting this principle serves primarily the Romanian state because businesses have a higher tax burden than using cash accounting and provides an accurate picture of its financial performance, although it is not accurate regarding liquidities.

2. Accounting principle of prudence in governing the recording and reporting financial transactions so that liabilities or income are not overstated and assets or expenses are not understated, taking into account depreciation, risks and possible losses arising from the current year or previous activity. [6]

This principle governs the enterprise`s profit and it aims towards declaring a minimum value to lessen its obligations to the state and moderate its optimistic image of the company to discourage creditors and to ensure a margin of safety.[1]

Expenditure incurred for depreciation or risk finding likely reduce profits. If tax rules recognized all such expenses as deductible it would mean that the state would participate in the risks taking which the company is subject to. [7]

Tax regulations regarding prudence are more restrictive, especially regarding deductibility of provisions, and only the following categories of provisions are recognised: provisions for risks and expenses (litigation, fines and penalties, claims, damages and other liabilities uncertain guarantees to customers and other provisions for 
risks and charges) and impairment of property, stocks and production in progress, receivables, marketable securities.

The result sheet is not accepted by the IRS and then it should be corrected, leading even to a profit tax accounting loss because it wants to prevent the operator to evade the payment of part of the tax.

3. Accrual principle

Under this principle one must take into account the income and expenditure for the financial year irrespective of the date of receipt or payment of such income and expenses. It provides an assessment of actual profitability and performance in line with reality.

Regarding this principle, there are differences between accounting and taxation in the events after the end of the year and the correction of accounting errors, because accounting rules accept accounting error correction of a prior period, even if the result affects the current period.

If it undermines the credibility of accounting information, the error will be corrected based on earnings and the Tax Code states that `revenues or expenses misstatement or omission is corrected by adjusting the taxable income of the tax period to which it belongs, and the taxpayer is required to submit a statement amendment for fiscal year and in case of an increase in the profit tax and income tax penalties are calculated and are dued not allowing modifications of the tax result for the current financial year.

4. The Continuity principle means that "he entity continues to operate normally, without going into liquidation or significant reduction of the activity. If an entity`s managers are aware of some elements of uncertainty related to certain events that may lead to its inability to continue work, these elements must be disclosed in the notes". [5] If financial statements are not prepared on the basis of this principle, fiscal perspective changes and they take the form of specific tax obligations.

For example, legal reserves established on account of gross profit in order to protect capital fluctuations encountered by the company, represent used profits which are nontaxable. During the winding, these profits are taxed retroactively, this constituting itself in a deviation from the accrual principle". ${ }^{[7]}$

5. Historical cost principal involves valuing goods entering the property, at cost, also called book value, and when leaving the property, evaluation of goods is done at the input value. Assets are held at cost, which are called historical cost except for reevaluations. Historical cost accounts are maintained with passive versus active-corrective depreciation and provisions. If there is an irreversible impairment, when inventory is recorded, an additional depreciation is registered, but in case of reversible impairment a provision for impairment is set in place.

Deductibility of expenses, procentage and time are of interest in taxation. To achieve a deferral of the tax burden, costs in the amount of input can be treated as expenses of the period, thus providing immediate and full deductibility of expenses, while their inclusion in the cost deductibility would mean postponing this until the exit of heritage for stocks and until record depreciation for assets.

These accounting principles are often used to manipulate the results of the company, sometimes even 'in an aggressive manner "to create a misleading picture of the company`s financial performance”. [4] 


\section{Evolution of Taxation and Economic Behavior in Romania}

In a World Bank study made in 2005 on the main causes of concern of companies, tax is the third and taxation seventh. Taxation is a key to economic instability in our country because of the many changes that have occurred since 1989, because establishing medium and long term strategies need a stable tax legislation. Businesses seem to be interested mainly in taxation legislation.

Income tax was introduced in 1991 after the appearance of the 15/1991 law on the reorganization of the state companies as autonomous and trading companies and 31/1991 low on trading companies. Technology assessment was unstable, modifying relatively frequently over time.

In 1991 , it was between $2.5 \%$ and $77 \%$, then changed to $30 \%$ for profits up to $1,000,000$ lei and $45 \%$ for profits exceeding 1,000,000 lei. After 1995, the tax rate was set at 38\%, and then to decrease to $25 \%$ at the end of 2004 and, from January 1 st 2005, it reached $16 \%$, which means for the Romanian State a reduction of income tax as shown in the table and the chart below:

\begin{tabular}{|c|c|c|c|c|c|c|c|}
\hline \multicolumn{7}{|c|}{ Millions/ lei } \\
\hline & $\mathbf{2 0 0 7}$ & $\mathbf{2 0 0 8}$ & $\mathbf{2 0 0 9}$ & $\mathbf{2 0 1 0}$ & $\mathbf{2 0 1 1}$ & $\mathbf{2 0 1 2}$ & $\mathbf{2 0 1 3}$ \\
\hline Tax & $26,319.0$ & $25,045.9$ & $31,829.9$ & $10,115.1$ & $10,309.1$ & $10,854.5$ & $10,925.7$ \\
\hline
\end{tabular}

Source: Developed by the author based on information provided by the Ministry of Public Finance.

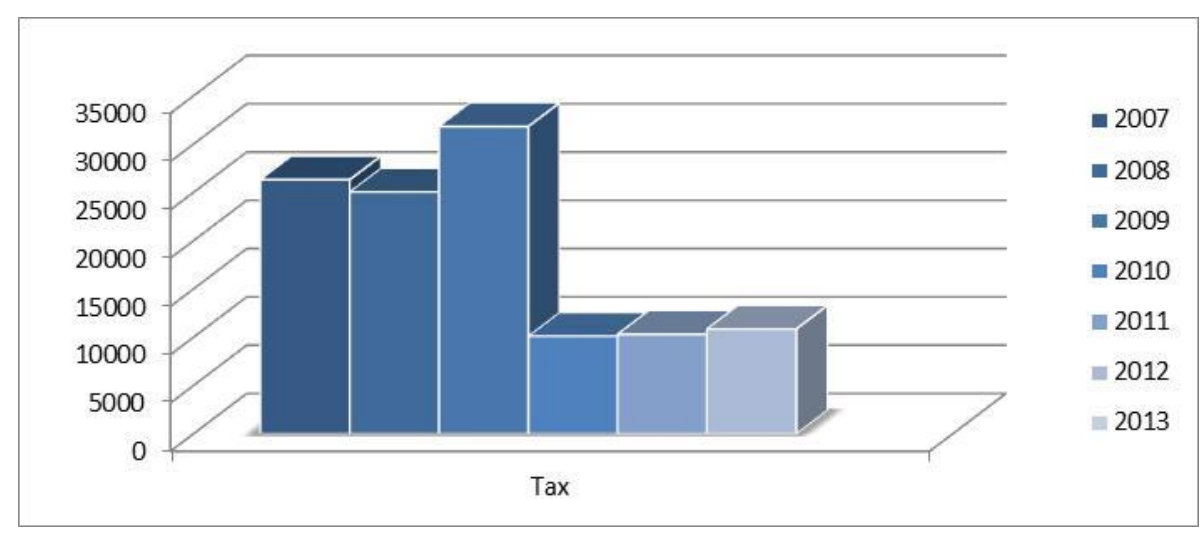

Source: Developed by the author based on information provided by the Ministry of Public Finance.

For the period under review there is a decrease in tax revenue collected by the state compared to the year 2007, followed by an increase of about 6,000 million in 2009 . During the next years and by 2013 there was a significant decrease, reaching to 10925.70 million in 2013 due to changing fiscal requirements. Businesses have sought ways to evade paying income tax, thus practicing tax evasion.

This phenomenon is continuasly growing and it means huge losses for the Romanian state, reaching up to 54 millions euros daily and according to the National Institute of Statistics, Romania`s tax evasion represents $30 \%$ of GDP. 


\section{Global Corporate Tax}

Income taxes vary considerably from one country to another, being countries where no tax is levied, but also countries where the income tax is very high.

In 2014, the company KPMG conducted a study called "Direct and indirect taxes," in which profit tax rates is also approached.

Further, the highest ten percent of income tax are exposed in the following table:

\begin{tabular}{|ccl|}
\hline Rank & Curent rate & Country \\
\hline $\mathbf{1}$ & $55 \%$ & United Arab Emirates \\
\hline $\mathbf{2}$ & $40 \%$ & United States \\
\hline $\mathbf{3}$ & $35.64 \%$ & Japan \\
\hline $\mathbf{4}$ & $35 \%$ & Angola, Argentina, Malta, Sudan, Zambia \\
\hline $\mathbf{5}$ & $34.5 \%$ & St. Maarten \\
\hline $\mathbf{6}$ & $34 \%$ & Brazil, Pakistan, Venezuela \\
\hline $\mathbf{7}$ & $33.99 \%$ & Belgium, India \\
\hline $\mathbf{8}$ & $33.33 \%$ & France \\
\hline $\mathbf{9}$ & $33 \%$ & Namibia \\
\hline $\mathbf{1 0}$ & $32 \%$ & Mozambique \\
\hline
\end{tabular}

Source: Developed by the author based on information provided by KPMG International.

In contrast, the lowest corporate tax rates in 2014 are:

\begin{tabular}{|ccl|} 
Rank Curent rate Country \\
\hline $\mathbf{1}$ & $9 \%$ & Montenegro \\
\hline $\mathbf{2}$ & $10 \%$ & Bosnia and Herzegovina, Bulgaria, Gibraltar, Macedonia, Paraguay, Quatar \\
\hline $\mathbf{3}$ & $12 \%$ & Macau, Oman \\
\hline $\mathbf{4}$ & $12.5 \%$ & Cyprus, Ireland, Liechtenstein \\
\hline $\mathbf{5}$ & $14 \%$ & Jordan \\
\hline $\mathbf{6}$ & $15 \%$ & Albania, Georgia, Iraq, Kuwait, Latvia, Lebanon, Lithuania, Mauritius, Serbia \\
\hline $\mathbf{7}$ & $16 \%$ & Romania \\
\hline $\mathbf{8}$ & $16.5 \%$ & Hong Kong \\
\hline $\mathbf{9}$ & $17 \%$ & Singapore, Slovenia, Taiwan \\
\hline $\mathbf{1 0}$ & $17.92 \%$ & Switzerland \\
\hline
\end{tabular}

Source: Developed by the author based on information provided by KPMG International.

United Arab Emirates had the largest share of direct taxes (55\%), followed by the US $(40 \%)$ and Japan (38\%), according to data of the study KPMG International "Direct and indirect tax rates." The reduced profit tax rate is registered in Montenegro, 9\%, following several states with a level of 10\%, including Serbia, Cyprus, Paraguay and Qatar.

In Romania, profit tax rate has been maintained at $16 \%$ since 2005 , when it was introduced flat. This low level of corporation tax attract investors. However, this asset of our country is diminished by numerous legislative changes in the field of direct taxation, blur, contradictory or insufficiently regulated administrative and judicial inefficiency. 


\section{Conclusions}

Taxation still has a pretty big influence on Romanian accounting practice. Romanian accounting provides information so the state can charge tax obligations of operators in our country because the state is the main user of the financial statements of companies.

For this reason, businesses are always looking for ways to dodge the payment of such obligations, both legally by manipulating financial statements using accounting policies and other ways that break the law. Both ways affect revenues collected by the state and they are constantly increasing, although the state uses various ways to inhibit these trends.

Accounting and taxation have their own ways which make them work but in the accounting of an enterprise one must take into consideration the fiscal rules because the crucial role in the relationship between the two is the political factor.

This paper shows the way taxation affects the financial result and how accounting can deal with these influences through accounting policies and methods in order to ensure reliable information.

As described in this paper, the corporate tax is higher in regions such as Asia, Africa or America, while in Europe, states have lower rates of corporation tax.

Further study on corporate tax and financial result of a company will continue to observe which are the ways through which the company will try to manipulate financial results.

Also here, it follows the evolution of corporate tax both in Romania and internationally, as the corporate income tax rate is one of many aspects of what makes a country's tax code and economy attractive for investment.

Romania should be advantaged by the low value of the profit tax rate of only $16 \%$, but our country is losing competitiveness due to fiscal instability.

\section{References}

[1] Popa, Florentina, (2011) „Contabilitatea şi fiscalitatea rezultatului intreprinderii”, Ed. CECCAR, Bucureşti,

[2] Ristea Mihai, Dumitru Corina, (2012), „Libertate și conformitate în standardele si reglementările contabile”, Ed. CECCAR, București,

[3] Istrate, Costel, (2000) "Fiscalitate si contabilitate în cadrul firmei", Ed. Polirom, Iasi,

[4] Răileanu, Vasile( coord.), (2010), „Contabilitate creativă- suport de curs și aplicații practice”, Academia de Studii Economice Bucuresti, București,

[5] Moisescu, Florentina, (2007) „Bazele contabilității”, Ed. Europlus, Galați

[6] Regulamentul de aplicare a Legii contabilității

[7] Domnişoru Sorin,(2004), "Controverse şi concilieri în gestiunea fiscal-contabilă a firmei”, Editura Sitech, Craiova

[8] Ordinul Ministerului de Finanțe Publice nr. 3055/2009 pentru aprobarea reglementărilor contabile conforme cu Directivele Europene;

[9] Standardele internaționale de raportare financiară: IFRS: norme oficiale emise la 1 ianuarie 2009/Fundaţia Comitetului pt. Standardele Internationale de Contabilitate, Editia a 4-a, revizuită, Editura CECCAR, Bucureşti, 2009;

****Legea 82/1991 cu modificările si completările ulterioare;

****Legea 571/2003 coroborată cu HG 44-2004 privind Codul Fiscal cu normele metodologice de aplicare;

**** www.mfinante.ro

**** www.insse.ro

**** www. ziare.com 